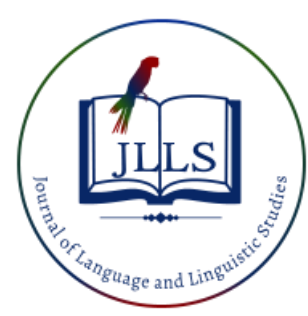

Available online at www.jlls.org

\title{
JOURNAL OF LANGUAGE
} AND LINGUISTIC STUDIES

ISSN: 1305-578X

Journal of Language and Linguistic Studies, 17(2), 1045-1057; 2021

\section{The impact of COVID-19 lockdown on UiTM Melaka Students' learning}

\author{
session
}

\author{
Nurul Asma Mazlan a 1 iD, Nurhafizah Mohd Zolkapli b iD, Wan Musyirah Wan Ismail ${ }^{\text {c }}$ iD, \\ Nur Aqilah Norwahi ${ }^{\text {d }}$, Mohd Faizulamri Mohd Saad ${ }^{\text {e }}$ iD \\ ${ }^{\mathrm{a}, \mathrm{d}}$ Academy of Language Studies, Universiti Teknologi MARA \\ ${ }^{b, c}$ Faculty of Business and Management, Universiti Teknologi MARA \\ ${ }^{\mathrm{e}}$ Research Centre for Quran and Sunnah, Faculty of Islamic Studies, Universiti Kebangsaan Malaysia
}

\section{APA Citation:}

Mazlan, N.A., Zolkapli, N.M., Ismail, W.M.W., Norwahi, N.A., Saad, M.F.M. (2021). The impact of COVID-19 lockdown on UiTM Melaka Students' learning session. Journal of Language and Linguistic Studies, 17(2), 1045-1057. Doi: 10.52462/j1ls.73

Submission Date: 10/02/2021

Acceptance Date:12/05/2021

\begin{abstract}
The purpose of this study was to determine the impact of the Restricted Movement Order (RMO) due to COVID19 to March - July 2020 semester students of Universiti Teknologi MARA (UiTM) Malacca. Through a confirmatory factor analysis, the student understanding scale was validated in three dimensions: technology acceptance, teaching approach and student readiness in the practice of Open and Distance Learning (ODL). The article also analysed the relationship between student understanding and the three variables. A total of 370 respondents had been selected using the purposive sampling method using SPSS analysis. The result showed that there is a weak relationship between the teaching approach and student understanding with the correlation of 0.355 . It is followed by the moderate relationship between teaching approach and student understanding with the correlation of 0.613 . Meanwhile, student readiness and student understanding have been identified as a very strong relationship with the correlations of 0.743 . The findings also found that student readiness has the highest mean as compared to other factors. This result specified that the students of UiTM Melaka are not fully prepared mentally and physically for an inclusive ODL approach. They felt that ODL is very incumbering and difficult in understanding the content of learning sessions especially for the subjects related with calculations.
\end{abstract}

Keywords: COVID-19; open distance learning; Restriction Movement Order (RMO); student understanding; teaching approach and student readiness; technology acceptance.

\section{Introduction}

The outbreak of COVID-19 in Wuhan, China, at the end of 2019, was considered as a major public health emergency because of the unusual fast rate in which the virus was spreading, the widest scope of infection, and the most difficult to prevent and control in China since its establishment (Willian \& Chew: 2020; Moritz et. al: 2020; Longjun et. al: 2019) until it spread rapidly to other countries all over the world (Andrea \& Giuseppe: 2020; Catrin et. al: 2020; Hien Lau et. al: 2020) including Malaysia

\footnotetext{
${ }^{1}$ Corresponding author.

E-mail address: asmamazlan@uitm.edu.my
} 
(Lekhraj \& Liew: 2020). Affected by these pandemic outbreaks, the Malaysia government requires departments of all levels to organize forces to limit or stop crowd gathering and requires non-essential enterprises to suspend production and business operations as well as normal economic and social activities (Naomi et. al: 2020). Moreover, the education sector in Malaysia was also affected because of the Restriction Movement Order (RMO) that has been enforced on 18 March 2020 for 14 days due to the rising number of infected COVID-19 cases (Berita Awani, 2020). Subsequently, the Malaysian Prime Minister extended the RMO period until 28 April 2020 since the positive cases and fatality rate kept on increasing in which 4683 cases had been reported with 76 deaths (WHO et. al, 2020).

Furthermore, due to this pandemic outbreak, it was also affecting Malaysia's education system in both school and tertiary levels. To avoid unsafe social contact between lecturers and students that can cause the situation to become worse, all teaching and learning activities must be held through online platforms. Universiti Teknologi MARA (UiTM) had introduced a full fletch Open and Distance Learning (ODL) for one semester starting from 13 April 2020 until the end of the current semester, scheduled in July 2020.

Evidently, overcoming the COVID-19 outbreaks (Wunong et. al, 2020) had been a priority for Malaysia, however, the teaching and learning process needed to be continued by focusing on online teaching and learning sessions (Gorka et. al, 2020). Based on the statement made by the Minister of Science, Technology, and Innovation (Bicara Awani, 14 April 2020), COVID-19 indirectly showcased the dilemma of digital illiteracy. This issue was not only faced by Malaysian but also students in the United States of America as well as other countries around the world. Because of this reason, it became important to spread common awareness to all lecturers to emphasize and focus on empathy elements as an effort to deliver knowledge and information to the students during RMO (KPT Guidelines: 2020). Besides, there were several learning strategies that were appropriate for this situation which included mobile ubiquitous learning (u-Learning) which is a learning strategy that integrates mobile technology that enables learning to be carried out without limits (seamless), anywhere, anytime, and in any way (according to the context of learning) based on the characteristics, needs/desires of students. Each learning activity consists of activities before class (online), offline/online, and activities after class (online). The principles of mobile ubiquitous learning included (1) mobility, (2) adaptability, (3) accessibility, (4) interactivity, (5) interoperability, (6) immediacy, (7) permanency, (8) pervasiveness, and (9) context awareness (Naib Canselor UiTM: 2020).

The concept of open learning and distance education system focuses on open access to education and training to make the learners free from the constraints of time and place and offering flexible learning opportunities to individuals and groups of learners. ODL reportedly was one of the most rapidly growing fields of education since many years ago, even nowadays, and it has a substantial impact on all education delivery systems (Bates, 1995; Bosch, 1997 and Bradley \& Yates, 2000).

The term ODL reflects both the fact that all or most of the teaching is conducted by someone who is away from the learner, and that the mission aims to include greater dimensions of openness and flexibility, whether in terms of access, curriculum or other elements of the structure. ODL systems could usually be described as made up of a range of components such as: the mission or goal of a particular system, programs and curricula, teaching/learning strategies and techniques, learning material and resources, communication and interaction, support and delivery systems, students, tutors, staff and other experts, management, housing and equipment, and evaluation (Saima et. al, 2012).

The use of technology was the main challenge for medium and lower income families in adapting ODL in their households. According to Datuk Freida Mohd Pilus (2020) technology is the limitation for learning activities at home. She did not encourage educators to give too many homework to be completed by the students. She further explained that it was not the right time to overload students 
with homework and it should be enough if the students could master the only selected concepts which were critical in their learning process. Yet, the situation became more difficult when most of the students did not bring home their books, notes and learning materials since they assumed the RMO period would end after 14 days and they could return to the hostels afterward.

In the search of the most suitable online platforms to be utilised by lecturers and students at home, according to Mohd Jasmy et. al (2020), he believed that although there were various online platforms available, WhatsApp and Telegram applications should be highlighted and recommended because of their low data usage, downloadable pictures and videos as well as voice recording function. This opinion aligned with the finding of the study conducted by William (2018) who indicated that about $80 \%$ of students agreed to use WhatsApp and Telegram as online learning platforms because both are user friendly, easy to access, suitable for the students who lived in rural areas and have poor internet connection as well as it is also conformable to the teaching process that is intended to be delivered.

Nevertheless, this 'forced' ODL has its issues. While the learning process is carried on, it does not take into account the learning or for that matter the teaching styles/personality that takes place in the face to face classroom. There are technological options, but they are not the same as the face to face and students with dated technology may find it difficult to keep up. For example, after several attempts to download an online test, it was discovered that a student's computer was 'old' and not compatible. That said, if students wanted online classes, they would have registered for them and not be in the brick and mortar buildings.

The "crisis" has tremendously altered the scheduled classes and assignments. Alternatives need to be devised to accommodate the missed assignments that would take place during the shutdowns. This is a challenging time and the need for flexibility and creativity will be the key to successfully getting through the "crisis".

\section{Literature Review}

The education system continuously experience transformation and innovation in a very fast pace aligned with the advancement of new technology (Yu, 2013). Now, mobile devices are owned mostly by everyone all around the world. Although the teaching and learning via mobile devices have only been acknowledged recently in the education field (Greg \& Ruth, 2018), yet, it has been proven to have many advantages and benefits especially in language curriculum (Thong \& Chien, 2016). Furthermore, mobile devices have been almost a necessity for lecturers and students especially in the current situation because they were equipped with various functions including internet access, media player, digital camera, and video recorder (Zhuo \& Yang, 2016).

In the tertiary level, mobile devices have become the most preferred and widely used tools as they could be accessed by almost all university students (Amanda, 2012 \& Chen, 2008). This advantage has made the use of mobile devices such as smart phones, PDA, and tablets beyond the other Information and Communication Technology (ICT) devices. Pellerin (2014); Traxler (2013); Kukulska-Hulme (2012); al-Fahad (2009) and Klopfer \& Squire (2008) added that, the benefit of these devices included, first: portability - the nature of the devices that light and easy to carry to anywhere. Second: mobility it indicated the accessibility of source even if both users and devices were on the move. Third: connectivity - the availability of cellular data on respective devices gave power to the users to contact others around the world at anywhere and anytime. Fourth: personality - not only users could adapt with the devices by suitable ways based on their priority, but also could search for information that had been suited with their requirement or a specific request.

However, Godwin-Jones (2011); Stockwell (2010) dan Ballard (2007) found that smartphones had several weaknesses such as small screen interface, and this would require a lot of times to scroll the 
interface, the low lifespan of the batteries (Sampson et. al: 2013; Kukulska-Hulme \& Traxler: 2005) and difficulty to type because of the small keyboard (Zhang: 2012; Stockwell: 2010).

Even though these devices had their weaknesses, they still became the preferred devices among students. Based on the study conducted by Campos (2017), it indicated that more than 2 billion students used mobile devices in the English language curriculum at universities, while Malaysia ranked in fifth from the respective list which is $68 \%$ from the total percentage that had been stated. Based on this percentage, it specified that the English language lecture already fully utilized the respective platforms in their teaching during class or outside class sessions.

If this platform already proved it had been successfully used in the English language curriculum, thus, other lecturers should also emphasize it in their curriculum. There were three main reasons why they needed to use this platform. First: learning through mobile devices would increase the total learning hours of the student with the flexibility to access the content of the topics at any times by depending on the suitability of their own learning time. Therefore, these facilities would add new knowledge and expand the skills to solve problems in language activities (Liu et. al: 2014). Second: students were able to provide instantaneous feedback towards learning language communication requested by their lecturer (Campos \& Freitas: 2015; Valk et. al: 2010). They would continuously search for new words easily, would be more active participants, and they would compete with one and another to complete the activities that have been instructed as compared to learn in the physical classes. This teaching design was the main key to the effectiveness of the learning process through mobile devices. Third: students also would respond faster towards listening and reading activities (Campos: 2016).

In the middle of December 2019, the world has been shaken with COVID-19 outbreaks in China (Willian \& Chew: 2020; Moritz et. al: 2020; Longjun et. al: 2019). Subsequently, it spread rapidly to other countries all round the world (Andrea \& Giuseppe: 2020; Catrin et. al: 2020; Hien Lau et. al: 2020) including Malaysia (Lekhraj \& Liew: 2020). Due to the effects of this deadly pandemic, the eighth Prime Minister of Malaysia declared RMO that had been enforced on 18 March 2020 for 14 days because of the infected cases of COVID-19 continuously increased (Berita Awani: 16 Mac 2020). Then, he extended the RMO period until 12 May 2020 because of the infected case and the mortality number gradually rose, in which 5851 cases were reported with 100 deaths (Ministry of Health Malaysia: 2020).

However, despite having to go through the difficult situation and in a fight to overcome this pandemic, teaching and learning sessions should still continue (Wunong et. al, 2020) by completely focusing on online learning (Gorka et. al: 2020). Based on the guidelines of several public universities such as UiTM, Universiti Kebangsaan Malaysia (UKM), Universiti Putra Malaysia (UPM), and Universiti Malaya (UM), the enforcement of teaching and learning as well as evaluation are through ODL with the approaches of suitable platforms such as Zoom, Google Meet, Google Hangouts, and Skype, among others. Through these platforms, lecturers and students could continue teaching and learning sessions face to face although without physical attendance. Full fletch of online teaching and learning sessions were very relevant to be applied in universities since it was deemed the best approach for flexible learning (Anchalee \& Jonathan, 2016).

Moreover, Anchalee and Jonathan (2016) stated that the main challenge in handling teaching and learning via online live interaction was students' commitment. Many of the students skipped online classes and took them for granted by not participating in online discussions or tasks. They felt that the lecturers were not strict enough when they conducted teaching via online class. Besides, some of the students were only "seen" online but not available in front of the computer or laptop to follow the lessons. Furthermore, there were also students who did not bring home their laptop because they 
thought that the RMO period was only for 14 days. Hence, they could only depend on the teaching and learning materials provided by the lecturers and search for additional information by their own in education websites and online journals via mobile devices. Gorka et. al (2020) added that, the use of technology was the main challenge for lecturers who did not really master the mobile technology especially much senior lecturers aged 50 years old and above. Nevertheless, Anchalee and Jonathan (2016) believed that this was not a huge problem since lecturers could attend any briefing, course, and training through online from the respective universities with teaching deliverable techniques in effective ways. Additionally, the lecturers could also record videos and then upload them on the university's online platforms.

Nevertheless, this situation became a bigger challenge when students reported to have a poor Internet connection which disabled them to access any websites or download ODL materials such as pictures and videos to aid their learning sessions. Mohd Jasmy et. al (2020) suggested to include WhatsApp and Telegram, aside from other platforms, as they both allow users to download photos, videos and audios with bite-sized data. This view is in parallel to a study by William (2018) where $80 \%$ of students agreed that WhatsApp and Telegram were more user friendly and easily accessed for ODL especially for students who lived in the outskirts and have a poor Internet connection.

Currently, WhatsApp and Telegram are not functioning only to relay messages and make calls, but they have become essential platforms in ODL. Not only inclusive to common subjects but also for lecturers teaching Arabic since it has shown effectiveness in teaching the language by adapting technology in lessons (Hassan Basri: 2005; Zawawi: 2005).

Hence, researchers believe that smartphones have become the best tool for ODL, especially during RMO. Teaching and learning sessions through WhatsApp, Telegram and digital photos sent via mobile technology proved to be effective as the objective of this innovative project are to explore the possible solutions to flexible teaching sessions which allow information access via different devices and at the same time facilitate various learning sessions.

\section{Methodology}

The primary data for this descriptive and analytical study was obtained through questionnaires administered to the diploma and degree students from UiTM Melaka in three different campuses that included UiTM Alor Gajah, UiTM Melaka Kampus Bandaraya as well as UiTM Jasin. A convenient sampling technique has been used in this study. The survey has been conducted through online by using Google Form to obtain the responses.

The entire population for this study was 10,709 students that came from 7 different faculties that available in UiTM Melaka which include Academic of Language Studies, Faculty of Art and Design, Faculty of Business and Management, Faculty of Computer Science and Mathematics, Faculty of Hotel and Tourism Management, Faculty of Communication and Media Studies and Faculty of Accountancy. The sample size for this study was 370 students that have been identified primarily by referring to the Krejcie and Morgan's table.

A five-point Likert-based scale were used to represent the most suitable answer of the from the respondents. The description of the Likert scales used included, 1-Strongly Disagree, 2-Disagree, 3Neutral, 4-Agree and 5-Strongly Agree. To test the reliability of the answers of the questionnaires, reliability analysis was used in the study. The reliability analysis has been conducted by referring to the rule of thumb made by Perry, Charlotte, Isabella, and Bob (2004). They described that Cronbach's alpha $(\alpha) 0.90$ and above shows excellent reliability, 0.70 to 0.90 shows high reliability, 0.50 to 0.70 shows moderate reliability and 0.50 and below shows low reliability. All factors of independent 
variables (technology acceptance, teaching approach, and student readiness) and dependent variables (student understanding) have been tested using SPSS. 20.0.

The study used mean, standard deviation, correlation and regression analysis to examine the relationship between technology acceptance, teaching approach, student readiness with student understanding. Besides, the analyses also have been carried out to identify the most influential factors that affect student understanding in ODL during RMO in UiTM Melaka.

\section{Findings}

\subsection{Descriptive Analysis}

This study represented 370 students who responded to the questionnaires distributed and they came from various faculties in UiTM Melaka. Majority of respondents were female $(n=269,72.7 \%)$. From all the respondents, majority were single $(\mathrm{n}=368 ; 99.5 \%)$ and only two of them; $0.5 \%$ were married. The highest of respondents were from Faculty of Business and Management ( $n=147 ; 39.7 \%$ respectively), Faculty of Science and Mathematics $(n=110 ; 29.7 \%)$, Centre of Language $(n=81$; 21.9\%), Faculty of Hotel and Management $(n=13 ; 3.5 \%)$, Faculty of Art and Design $(n=11 ; 3 \%)$, Faculty of Accounting $(n=5 ; 1.4 \%)$ and Faculty of Media and Communication $(n=3 ; 0.8 \%)$. Overall, students from Kampus Bandaraya Melaka is the highest number of respondents $(n=163 ; 44.1 \%)$, Kampus Jasin $(n=114,30.8 \%)$ and Kampus Alor Gajah $(n=93 ; 25.1 \%)$. The majority of the respondents were degree students $(n=241 ; 65.1 \%)$ and diploma $(n=129 ; 34.9)$. The highest majority age were 18 to 22 years $(n=307 ; 83 \%), 23$ to 27 years $(n=61 ; 65 \%)$ and 28 to 32 years $(n=2,0.5 \%)$.

\subsection{Reliability Test}

A reliability test was conducted to see the reliability of the constructs of the variables. Table 1 below shows the results of the Cronbach alpha value of the reliability analysis.

Table 1. Reliability Analysis

\begin{tabular}{|l|l|l|}
\hline No & Construct & Cronbach Alpha value \\
\hline 1 & Teaching approach & 0.722 \\
\hline 2 & Technology acceptance & 0.514 \\
\hline 3 & Student readiness & 0.876 \\
\hline 4 & Student understanding & 0.866 \\
\hline
\end{tabular}

\subsection{Correlation Analysis}

Table 2 shows the relationship between each variable. Based on the table, it shows that there is a weak relationship between the teaching approach and student understanding with the correlation of 0.355. It is followed by the moderate relationship between teaching approach and student understanding with the correlation of 0.613 . Meanwhile, student readiness and student understanding have been identified as a very strong relationship with the correlations of 0.743 . 
Table 2. Correlation analysis result for all variables

\begin{tabular}{|c|c|c|c|c|}
\hline & $\begin{array}{c}\text { Technology } \\
\text { Acceptance }\end{array}$ & $\begin{array}{c}\text { Teaching } \\
\text { Approach }\end{array}$ & $\begin{array}{c}\text { Student } \\
\text { Readiness }\end{array}$ & $\begin{array}{c}\text { Student } \\
\text { Understanding }\end{array}$ \\
\hline Technology Acceptance & 1 & $.378^{* *}$ & $.617^{* *}$ & $.613^{* *}$ \\
\hline Teaching Approach & $.378^{* *}$ & 1 & $.355^{* *}$ & $.436^{* *}$ \\
\hline Student Readiness & $.617^{* *}$ & $.355^{* *}$ & 1 & $.743^{* *}$ \\
\hline Student Understanding & $.613^{* *}$ & $.436^{* *}$ & $.743^{* *}$ & 1 \\
\hline
\end{tabular}

\subsection{Regression Analysis}

Table 3 below shows the results of regression for the total of three independent variables toward the dependent variable which is student understanding. Based on the table, it is shown that the value of $\mathrm{R}$ is 0.782 . The $\mathrm{R}$ value is the correlation of the three independent variables with the dependent variable. The table shows that 0.612 of the variances or also known as the $\mathrm{R}$ square of the student understanding is contributed by the three independent variables.

Meanwhile, the adjusted R Square value shows the value of 0.609 . Therefore, it could be concluded as 60.9 percent of the variation from the dependent variable is being attributed from the independent variable. This multiple regression analysis is being done as to test the three independent variables which are the technology acceptance, teaching approach and student readiness influence the student understanding. According to Table 4, it shows that all variables are significant to the dependent variables. Referring to the table, the Beta result shows a positive result of 0.208 for technology acceptance, 0.159 for teaching approach and 0.558 for student readiness. As for the significant result, it shows 0.00 for all the three variables which shows that they are very significant to the dependent variable. Thus, it can be concluded that student readiness is the most influential factor to student understanding because it has the highest beta 0.558 , followed by technology approach 0.208 and the teaching approach is the least factor for student understanding which is 0.159 .

Table 3. Linear Regression to evaluate the relationship of the independent variable and dependent variables

\begin{tabular}{|c|c|c|c|c|}
\hline & Model R & R Square & Adjusted R Square & $\begin{array}{c}\text { Std. Error of the } \\
\text { Estimate }\end{array}$ \\
\hline 1 & $.782 \mathrm{a}$ & .612 & .609 & .45438 \\
\hline
\end{tabular}

Table 4. Result of multiple regression

\begin{tabular}{|c|c|c|}
\hline & Beta & Sig \\
\hline Technology Acceptance & 0.208 & 0.000 \\
\hline Teaching Approach & 0.159 & 0.000 \\
\hline Student Readiness & 0.558 & 0.000 \\
\hline
\end{tabular}

\section{Discussion and Conclusion}

Overall, the findings of the study have shown that $61.2 \%$ of the independent variables which consist of technology acceptance, teaching approach and student readiness were influenced dependent variable which is student understanding. Whereas, another $38.8 \%$ has been influenced by other factors. 
Based on the result the study, it also indicates that student readiness has the highest mean as compared to other factors which are teaching approach and technology acceptance. This result has specified that the students of UiTM Melaka were not fully prepared mentally and physically to learn by using the ODL approach. They felt that ODL was very incumbering and it was strenuous to understand the content of learning sessions especially for the subjects related with calculations.

Besides, lack of facilities such as laptop and internet access were also the main challenges that had been faced by the students during ODL at home. The result was aligned with the study conducted by Folorunse et. al (2006), whereby, it revealed that the low acceptance of e-learning was due to the low awareness level, low computer literacy level, unreliable platform and internet services. Likewise, obstacles faced by universities included infrastructure and students' limited access to the computer (Iqbal \& Ahmad, 2010; Adah, 2012). Siritongthaworn et. al (2006) added that, the student reported to having limited access to a computer and the internet quality was inconsistent, especially at home. Many of the students explained that they usually used the computers provided at the computer labs in their universities without having to pay for the Internet, and also many reported to having difficulty in accessing online materials due to the lack of appropriate software. When they were at home, the situation became worse since the some areas had very limited internet access and most of them were using outdated computer systems (Vate-U-Lan, 2007).

Moreover, a lack of preparations among the students to employ ODL can be seen since the majority of them did not bring home their textbooks, class notes and other learning materials. This situation happened because the declaration of RMO has been made in a short notice by our Prime Minister since the positive cases of COVID-19 tremendously increased. Students were told to vacant the college residences and were sent home in less than two days. This resulted in them only bringing home their personal belongings and left the textbooks and class notes.

Additionally, students also could not give a full commitment on the normal class timetable during ODL and were not fully ready for ODL sessions since there were many obstacles such as they were required to do house chores as well as interference from their siblings. Besides, they also did not have enough times to complete their homework by using electronic technology facilities. This situation had caused the students to feel pressure and stress since they were expected to give full commitment towards online learning activities.

Meanwhile, based on the result of the study, it showed that $90.5 \%$ from the total percentage of the respondent chose Google Classroom as the main platform for learning activities during ODL, followed by WhatsApp (86.4\%), Google Meet (75.7\%), Telegram (67.4\%), I-learn (44.6\%), YouTube (29.3\%), Zoom (7.8\%) and Skype (6.4\%). This has proved that Google Classroom has become as the most preferred platform among students at UiTM Melaka since it enables the lecturers to upload teaching videos, notes and additional materials and assignments. For those students who do not really understand the learning content, they can refer to the teaching videos provided by their lecturers as many times as they want and at the same time they can ask the question to their lecturers online. This result can be supported with the study conducted by Noriyani (2017), in which students prefer the learning approaches using Google applications as compared to other platforms.

However, there were students who did not really prefer if the teaching and learning process was conducted in "live" interaction because they were new to this platform too. Apart from that, some students also were not good in using this kind of technology through computers, laptop or smartphones systematically although most of them have a smartphone. The researchers believe that, the students did not really use their smartphones in searching for the information that requires during their learning sessions. The students only used this device for making phone calls, chatting and for entertainment purposes. This view aligns with the study conducted by Anchalee and Jonathan (2016) where they 
indicated that universities students only searched for the information that was related with academics through smartphones if they were only instructed or assigned by their lecturers. Furthermore, Min et. al (2010) showed that the communication effectiveness through online is low and the majority of the students preferred to learn in physical classes as compared to online classes.

Even though the students had a lack of knowledge on the use of technology during ODL, they agreed that the lecturers really helped them to reduce their burden in the learning process. The teaching approach used by the lecturers was not really complicated and the lecturers did try to understand students' problems and at the same time ease the students' concerns to go through the ongoing semester that was full of challenges. The majority of UiTM Melaka students agreed that the lecturers already gave a full commitment in the teaching and learning process.

Hence, it can be concluded that most students were not physically and mentally ready for ODL in the current semester. In addition, lack of knowledge in the usage of technology has made it more difficult for students to practice ODL and lecturers have also struggled to ensure their ODL sessions to be effective and accessible to students. There were also students who voiced out their dissatisfactions towards university administrators as ODL was deemed to be implemented without taking in students' viewpoints. Nevertheless, it is understood by the researchers that any decisions made by the university administrators were also based on the consequences at students' end as students were given the options to further continue the semester via ODL or to postpone it.

\section{Future Research Recommendations}

The researchers believe that students with good ability to use various tools and technologies will enable them to participate in online learning more easily as it is also vital for the students to have a good technological background in order to be excellently involved in online learning, since they require to have some level of comfort while using the computer and web technologies (Lee \& Witta, 2001). Without good technological knowledge it becomes a hindrance for the students to take part in online learning. To increase the acceptance level among the student towards ODL sessions, it is very crucial for the management of the university to take several initiatives to provide technological trainings to the students. Even though we are in the middle of a pandemic, technological training can still be conducted online through Google Meet, Skype and Webex, among others. These training may be available through internal resources of institutions, such as the Information Technology department in a university. Correspondingly, training sessions can be conducted outside of the university from software vendors or IT experts from other educational institutions. According to Agarwal and Prasad (1998), training whether conducted internally or externally, is positively related to technology acceptance.

For future research, it is recommended that the researchers should broaden the population of the study to several other universities and not only focusing on one university, so that, the result of the study can be generalized. Finally, it is suggested that the future researchers should investigate or examine several factors other than technology acceptance that perhaps could affect student understanding during ODL sessions.

\section{References}

Addah, J. (2012). Computer Literacy and E-Learning: Attitudes among First Year Students in a Ghanaian Medical School. International Journal of Computer Applications, 51: 22

Agenda Awani, Pendidikan Era Normal Baharu. (2020, March 16). Retrieved from 19 March 2020. 
Amanda, R. Hurlbart. (2018). Online VS. Traditional Learning in Teacher Education: A Comparison of Student Progress. American Journal of Distance Education, 32(4): 248-266.

Anchalee Ngampornchai \& Jonathan Adams. (2016). Students' Acceptance and Readiness for eLearning in Northeastern Thailand. International Journal of Educational Technology in Higher Education, 34: 1-10.

Andrea Remuzzi \& Giuseppe Remuzzi MD. (2020). COVID-19 and Italy: What Next? The Lancet, 395(10231): 1225-1228.

Babbie, E. (2008). The Basics of Social Research. 4th ed. Belmont: Thomson Wadsworth.

Ballard, B. (2007). Designing the Mobile User Experience. USA: John Wiley \& Sons.

Bates A.W. (1995). Technology, Open Learning and Distance Education, London: Routledge.

Bosch, A. (1997). Interactive Radio for Instruction: TwentyThree Years of Improving Educational Quality, Educational Training Technology Notes Series 2, Washington, D.C., World Bank.

Bradley J and Yates C (Eds.). (2000). Basic Education at a Distance, World Review of Distance Education and Learning, London: Routledge Falmer.

Campos, A. A. \& Freitas, J. C. de. (2015). Assessing and Implementing English Learning Mobile Applications in a University Graduation Program: SLA 2.0. In Proceedings of the Computer Supported Education 2015, Lisbon, 23-25 May 2015. Portugal: INSTICC.

Campos, A. A. (2016). Linguistic Meaning in Self-Regulated Strategies: A Doctoral Research into Mobile Assisted Language Learning. In Newton Fund Conference on the Philosophies of Mind, Language and Action, 19-23 September 2016. Halaman: 31-32. Brasil: Universidade de São Paulo.

Catrin Sohrabi, Zaid Alsafi, Niamh O’Neill, Mehdi Khan, Ahmed Kerwan, Ahmed al-Jabir, Christos Iosifidis, Riaz Agha. (2020). World Health Organization declares global emergency: A review of the 2019 novel coronavirus (COVID-19). International Journal of Surgery, 76: 71-76.

Chen, C. (2008). Personalized Intelligent Mobile Learning System for Supporting Effective English Learning. Educational Technology \& Society, 11(3): 153-180

al-Fahad, F. N. (2009). Students' Attitudes and Perceptions Towards the Effectiveness of Mobile Learning in King Saud University, Saudi Arabia. TOJET: The Turkish Online Journal of Educational Technology, 8(2).

Folorunse, O. Ogunseye, O.S, \& Sharma, S.K. (2006). An Exploratory Study of the Critical Factors Affecting the Acceptability of E-Learning in Nigerian Universities. Information management \& Computer Security, 14(5): 496-505.

Fraenkel, JR. \& Wallen, N.E. (2008). How to Design and Evaluate Research in Education. $7^{\text {th }}$ Edition. McGraw-Hill Education, Europe.

Garis Panduan KPT. 2020. (27 March 2020). Retrieved from 5 April 2020. https://www.moe.gov.my/en/pemberitahuan/media-statement/kenyataan-media-pelaksanaanpengajaran-dan-pembelajaran-berikutan perlanjutan-tempoh-perintah-kawalan-pergerakan.

Godwin-Jones, R. (2011). Emerging Technologies: Mobile Apps for Language Learning. Language Learning and Technology, 15(2), 2-11.

Gorka Roman Etxebarrieta, Elizabeth Perez-Izaguirre, Argia Langarika-Rocafort. 2020. Teaching Minority Languages in Multiethnic and Multilingual Environments: Teachers' Perceptions of 
Students' Attitudes toward the Teaching of Basque in Compulsory Education. Journal of Education Science, 10(2), 25.

Greg Heiberger \& Ruth Harper. (2018). Using Social Media and Scientific Teaching to Enhance Undergraduate Learning. Learning Everywhere on Campus: Teaching Strategies for Student Affairs Professionals. Routledge: New York.

Hien Lau, Veria Khosrawipour, Piotr Kocbach, Agata Mikolajczyk, Hirohito Ichii, Justyna Schubert, Jacek Bania, Tanja Khosrawipour. (2020). Internationally Lost Covid-19 Cases. Journal of Microbiology Immunology and Infection. 14 March 2020. Page 1-5.

Iqbal, M.J \& Ahmad, M. (2010). Enhancing Quality of Education through E-Learning: The Case Study of Allama Iqbal Open University. Turkish Online Journal of Distance Education, 11, 84-97

Klopfer, E., \& Squire, K. (2008). Environmental detectives: The development of an augmented reality platform for environmental simulations. In Press for Educational Technology Research and Development, 56(2), 203-228.

Kukulska-Hulme, A. (2012). Language Learning Defined by Time and Place: A Framework for Next Generation Designs. In: Diaz-Vera, Javier E. Left to My Own Devices: Learner Autonomy and Mobile Assisted Language Learning. Bingley, UK: Emerald Group Publishing Limited. Page: 1-13

Kukulska-Hulme, A., \& Traxler, J. (2005). Mobile Learning: A Handbook for Educators and Trainers. London: Routledge.

Lekhraj Rampal \& Liew Boon Seng. (2020). Coronavirus Disease (COVID-19) Pandemic. Med J Malaysia, 75(2), 95-97. 2 March 2020.

Liu, M., Navarrete, C. C., Maradiegue, E., \& Wivagg, J. (2014). Mobile learning and English Language Learners: A Case Study of Using iPod Touch as a Teaching and Learning Tool. Journal of Interactive Learning Research, 25(3), 373-403

Longjun Zhou, Shanshan Wu, Ming Zhou \& Fangmei Li. (2019). 'School's Out, But Class' On', The Largest Online Education in the World Today: Taking China's Practical Exploration During The COVID-19 Epidemic Prevention and Control as an Example. Best Evid Chin Edu, 4(2): 501-519.

McBurney, D.H. (2000). Research Methods. Wadsworth Thomson Learning.

Min, Ling Hung, Chien Chou, Chao-HsiuChen, Zang-YuanOwn. (2010). Learner Readiness for Online Learning: Scale Development and Student Perceptions. Computers and Education, 55(3), 10801090.

Mohd Jasmy Abd Rahman, Mohd Hanafi Mohd Yasin, Mohd Isa Hamzah, Zolkepeli Haron, Md Yusoff Daud, Nur Kamariah Ensimau. (2020). Teaching and Learning-Assisted Learning Management System. Proceedings of the 3rd International Conference on Learning Innovation and Quality Education (ICLIQE 2019).

Moritz U. G. Kraemer, Chia-Hung Yang, Bernardo Gutierrez, Chieh-Hsi Wu, Brennan Klein, David M. Pigot. (2020). The effect of Human Mobility and Control Measures on the COVID-19 Epidemic in China. Science. 25 March 2020. Page 1-5.

Naomie Salim, Weng Howe Chan, Shuhaimi Mansor, Nor Erne Nazira Bazin, Safiya Amaran, Ahmad Athif Mohd Faudzi, Anazida Zainal, Sharin Hazlin Huspi, Eric Khoo Jiun Hooi, Shaekh Mohammad Shithil. (2020). COVID-19 epidemic in Malaysia: Impact of lock-down on infection dynamics. medRxiv the Preprint server for Health Sciences. 11 April 2020. Pages 1-27. 
Noriyani Binti Doman. 2017. Implikasi Google Apps dalam Pengajaran dan Pembelajaran Pelajar Pesisir UTHM. Fakulti Pendidikan Teknikal dan Vokasional Universiti Tun Hussein Onn Malaysia.

Pellerin, M. (2014). Language Tasks Using Touch Screen and Mobile Technologies: Reconceptualizing Task-based CALL for Young Language Learners. Canadian Journal of learning and Technology, 40(1), 1.

Perhimpunan Dwibulanan naib Canselor bersama Warga UiTM dalam Talian. 23 April 2020. Retrieved from 28 April 2020.

Perry, R. H., Charlotte, B., Isabella, M., \& Bob, C. (2004). SPSS Explained.

Sampson, D., Isaias, P., Ifenthaler, D \& Spector, J. (2013). Ubiquitous and Mobile Learning in The Digital Age. Springer Media.

Saima G., Joyshree N., Shalabh A., \& Asoke N. (2012): Open and Distance Learning (ODL) Education System: Past, Present and Future - A Systematic Study of an Alternative Education System. Journal of Global Research in Computer Science, 3(4), 53-57.

Siritongthaworn, S. Krairit, D. Dimmit, N.J \& paul, H. (2006). The Study of E-Learning technology Implimentation: A Preliminary Investigation of Universities in Thailand. Education and Information Technologies, 11(2), 137-160.

Stockwell, G. (2010). Using Mobile Phones for Vocabulary Activities: Examining the Effect of The Platform. About Language Learning and Technology. Page: 95.

Thong, Ann Sytwu \& Chien, Hwa Wang. (2016). An Investigations of The Effects of Individual Differences on Mobile-Based Augmented Reality English Vocabulary Learning. In Mobile Learning Design: Theories and Application. Springer Science Business Media Singapore Pte. Ltd.

Traxler, J. (2013). Mobile learning for languages: Can the Past Speak to The Future? Monterey, CA: The International Research Foundation for English Language Education. Retrieved from 7 Mei 2020.

Valk, J., Rashid, A., \& Elder, L. (2010). Using Mobile Phones to Improve Educational Outcomes: An Analysis of Evidence from Asia. International Review of Research in Open and Distance Learning, 11(1), 117-140.

Vate-U-Lan, P. (2007). Readiness of E-Learning Connectivity in Thailand (Conference Paper Presented at the Fourth International Conference on E-Learning for Knowledge-Based Society, November 18-19. Bangkok, Thailand).

Willian Kidman \& Chew-Hung Chang. (2020). What Does 'Crisis' Education Look Like? International Research in Geographical and Environmental Education, 29(2), 107-111.

William Kofi Koomson. 2018. Leapfrog Technologies: Can Mobile Technologies Competes Successfully with Traditional Learning Management Systems? Advances in Social Sciences Research Journal, 5(8), 234-250.

WHO et al. confirmed Covid Cases and Deaths in ASEAN. Update 12 April 2020. Retrieved from 7 Mei 2020.

Wunong Zhang, Yuxin Wang, Lili Yang, Chuanyi Wang. (2020). Suspending Classes Without Stopping Learning: China's Education Emergency Management Policy in the COVID-19 Outbreak. Journal of Risk Financial and Management, 13(3), 55. 
Yu-Liang Ting. (2013). Using Mobile Technologies to Create Interwoven Learning Interactions: An Intuitive Design and Its Evaluation. Elsevier: Science Direct. Journal of Computers and Education, 60(1), 1-13.

Zhang, F. (2012). Computer-Enhanced and Mobile-Assisted Language Learning. Information Science Reference: USA.

Zhuo Wang \& Yang Cui. (2016). Mobile Assisted language Learning in China's College English Education: The Reality and Research. In Mobile Learning Design: Theories and Application. Springer Science Business Media Singapore Pte. Ltd

\section{AUTHORS BIODATA}

Nurul Asma Mazlan is currently lecturer at Academy of Language Studies, Universiti Teknologi MARA (UiTM). Her main teaching and research interests include Arabic Language and literature

Nurhafizah binti Mohd Zolkapli is currently lecturer at Faculty of Business and Management, Universiti Teknologi MARA (UiTM). Her main teaching and research interest is Office management.

Wan Musyirah Binti Wan Ismail is currently lecturer at Faculty of Business and Management, Universiti Teknologi MARA (UiTM). Her main teaching and research interest is Islamic finance.

Nur Aqilah binti Norwahi is currently lecturer at Academy of Language Studies, Universiti Teknologi MARA (UiTM). Her main teaching and research interest is English Language.

Mohd Faizulamri Mohd Saad is currently lecturer at Faculty of Islamic Studies, Universiti Kebangsaan Malaysia (UKM). His main teaching and research interests include Qiraat, Ulum Quran and Tafsir. 